\title{
Analysis Of Related Party Classification Based On Indonesian Tax Law And Tax Treaty Indonesia-Japan
}

\author{
Gupto Andreantoro ${ }^{1}$, Deva Agung Mahendra² \\ Master of Administration, Majoring in Tax Management \\ Institut STIAMI \\ Email: deva.agung10@gmail.com \\ guptoandre@gmail.com
}

DOI: 10.29322/IJSRP.11.01.2021.p10971

http://dx.doi.org/10.29322/IJSRP.11.01.2021.p10971

\begin{abstract}
A related party between an entity that has the power to influence the entity either directly or indirectly, such as equity participation, family relationships, management control and technology. This study aims to analyze the related party tax based on Indonesian law and the Indonesian tax treaty with Japan. Researchers used a qualitative explanative research type in this study. To obtain the required data, researchers conducted data by means of study literature, observation and documentation. The results of this study produce information that there is no related party between Indonesia and Japan based on information and data obtained from the Income Tax Law and Article 9 P3B Indonesia and Japan. It can be concluded that P3B only limits domestic law and does not give new taxation rights to countries implementing $P 3 B$ so that the rules or laws used in the case of related party between Indonesia and Japan are based on domestic law.
\end{abstract}

Keywords: Related Party, Tax Treaty, Lex Specialis, Lex Generalis, Indonesia - Japan.

\section{INTRODUCTION}

Taxes are revenues received by developing or developed countries. In Indonesia, tax is the main stage of the state because almost all state activities are financed through taxes. To run the government, of course, many things are needed, such as carrying out development planning. Therefore, funds are needed which are of course quite large in development and these funds have increased every year in line with community needs. The need will be obtained through domestic revenue sources and one of the revenues obtained through the taxation sector. Taxes have an important role, especially in the economy of a country, because these taxes can be used in infrastructure development and other activities aimed at the welfare of its people. Taxes received from the public will also be given to the community in the form of facilities and aim at the convenience of each citizen.

State revenue can be obtained from the trade sector. Trade is an activity that is always in the environment around us. Products from this trade are services or goods that are produced and then sold and consumed by consumers. This trade will certainly benefit those who sell or buy because the seller benefits from their sale, then from the buyer's side also benefits from obtaining the goods or services needed. In the current era of globalization, trade does not only occur within the country, but can also occur abroad or is called international trade. International trade can occur because of the existence of multinational companies as traders who want to run their business in several countries. The goal of multinational companies is to make a profit on the goods sold or produced and to expand market share.

Because multinational companies conduct transactions in different countries, of course, the tax rates received will also be different. Taxation transactions that occur on international trade are called international taxes. International tax is a tax treaty that is agreed upon by a country that has a Double Taxation Avoidance Agreement (P3B) or the so-called Tax Treaty. Tax Treaty (P3B) is a taxation agreement agreed upon by two

countries which aims to minimize double taxation and various tax avoidance efforts. Tax avoidance efforts are often carried out by multinational companies by shifting profits through transactions between several related parties in different countries. The shift in 
ISSN 2250-3153

profit can also occur in a country that is domiciled in the same country by using the difference in tax rates in the final or non-final income tax sector for certain businesses.

In this world, there are two treaty models that are used as references in preparing a treaty, namely the OECD Model and the UN Model. The goal of the OECD Model is to increase trade between a country that signed a P3B by eliminating double taxation internationally, while the UN Model aims to increase foreign investment into developing countries and achieve economic and social growth of developing countries. Transactions between related parties are known as affiliated transactions, then for the price agreed in a special relationship is known as transfer pricing. The definition of a special relationship has been regulated in Article 18 paragraph (4) of Law Number 36 Year 2008 Fourth Amendment to Law Number 7 Year 1983 concerning Income Tax which regulates special relationships in paragraphs (3) and (3a), Article 18 paragraph (4), Article 9 paragraph (1) letter f, and Article 10 paragraph (1), can be said to have a special relationship if:

1. Taxpayers have direct or indirect investment in other taxpayers with a rate of at least $25 \%$ or taxpayers with two or more taxpayers who have capital participation of at least $25 \%$.

2. Taxpayers who control one or more other taxpayers either directly or indirectly. Examples of mastery are through management and use of technology.

3. Having a family relationship either by blood or by blood.

These three things are criteria for a special relationship based on Domestic Law. So it can be said that taxpayers have a special relationship with other taxpayers if they meet the criteria in Article 18 paragraph (4) of the Income Tax Law. A special relationship is closely related to transfer pricing. Motivation in transfer pricing can be in the form of reducing tax objects, especially income taxes, minimizing the risk of foreign company activities and to survive from import competitors. Transfer pricing also aims to control the performance of foreign branches or subsidiaries, to prevent foreign governments from participating in these transactions, to control cash flows of branches or affiliated subsidiaries and to evaluate the performance of each division.

In international taxation there is what is known as a general principle (lex generalis) and also a special principle (lex specialis). What becomes a lex specialis is a tax treaty and domestic law becomes a lex generalis. What this means is that tax treaty is in essence higher than domestic law, so that tax treaty can only limit taxation rights but cannot provide new taxation rights to countries implementing tax treaty. So if the tax treaty regulates that there is a taxation right on certain income, but in domestic law it regulates that certain income is not subject to income tax, then the country cannot impose tax on certain income even though the tax treaty provides taxation rights to that country. (Wisanggeni, 2019).

In International Taxes, cases often occur due to differences in regulations between tax treaty and domestic law. Because of these differences, many taxpayers forward the case to the tax court to obtain the truth between the two rules. Therefore, the author will discuss the international tax case between Indonesia and Japan. In this case, the background was that the tax authorities obtained data that there was an affiliation relationship between PT ABC and a Japanese company due to management supervision or control. But in reality, PT ABC has absolutely no affiliation with Japanese companies in terms of supervision or management control. PT ABC also does not meet the criteria for an affiliation relationship based on Article 18 paragraph (4) of the Income Tax Law.

The Japanese company has no special relationship with PT ABC because its share ownership is only 9.5\%. Then the Japanese company did not control PT ABC either directly or indirectly. In management control, there is no the same name on the position of the Board of Director (BoD) based on the information on SPT Badan PT ABC with Japanese companies. In carrying out its business, PT ABC runs independently and without being controlled by any party. Then for the use of technology, PT ABC also does not use technology from Japanese companies in running its business. There is no family relationship between PT ABC and Japanese companies, either blood or blood. So according to domestic law, PT ABC does not meet the criteria for a special relationship with a Japanese company.

The tax authorities continue to say that there is a special relationship even though the domestic law clearly does not meet the criteria. The basis of the statement made by the tax authorities is based on the tax treaty (P3B), so that although according to domestic law there is no special relationship, it is still unacceptable, because the tax treaty (P3B) is a lex specialis, so domestic law must follow the rules of the tax treaty. Based on this chronology, the authors are interested in conducting research because there are differences between domestic regulations and tax treaty $(\mathrm{P} 3 \mathrm{~B})$.

\section{RESEARCH QUESTION}

Until now, there have been many differences of opinion between taxpayers and Fiskus regarding the determination of a special relationship. In addition, this can also be used as loop holes for both Taxpayers and Fiskus in determining transfer prices. For taxpayers, this gap can be used to make profit shifting to its parent companies, while for Fiskus, this gap can be used as an excuse to make comparative corrections on transactions made by taxpayers. Of course, this is very contrary to the principle of tax, namely certainty that: "tax laws and regulations must be comprehensive to the taxpayer, they must be unambigous and certain, both to the taxpayer and to the tax administrator."

Based on the background and previous phenomena, it can be described in the following research questions: "How is the classification of a special relationship based on the tax laws in Indonesia and the Indonesia - Japan double tax treaty?" 


\section{RESEARCH THEORY}

\section{Special Relationship}

According to David Grecian, in the IFA (International Fiscal Associated) congress, control is the capacity of a company to dominate decision-making in financial operations or intercompany policies, including the influence of market control and economically independent companies. The fairness of the price for the transfer of tangible and intangible goods in exchange for the transfer of services also in the taxation provisions in many countries provisions are regulating the tax administration authority to examine the fairness of the price or compensation. Each country has its own concept of fairness research on transactions involving special relationships.

Some countries can determine whether a transaction occurs naturally or not regardless of who is transacting, while some see who is transacting which is commonly referred to as the quality approach. Based on this approach, if any party transacting is the transacting party, it is an independent party without any significant relationship that can influence the policy of the amount of price or compensation for deviating from prices that are acceptable on the free market. Thus, regardless of the price or consideration to be received (by the tax administration) and considered a fair market price, if there is a relationship that may affect, the administration can recalculate the price considered for the transfer of services. (Gunadi, International Tax, 2007). The special relationship scheme can be described as below:

1. Company $\mathrm{X}$ in Country $\mathrm{X}$ participates either directly or indirectly in the management, control, or capital ownership of company Y in Country Y.

\section{Special Relationship Scheme}

Directly

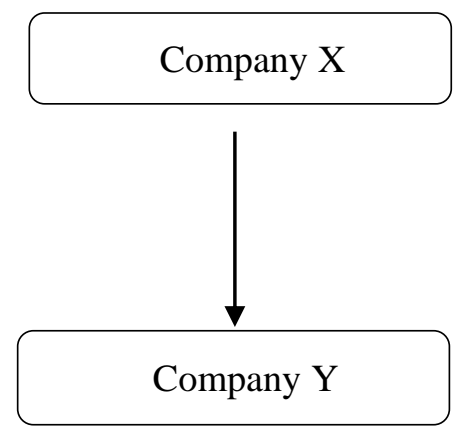

Indirectly

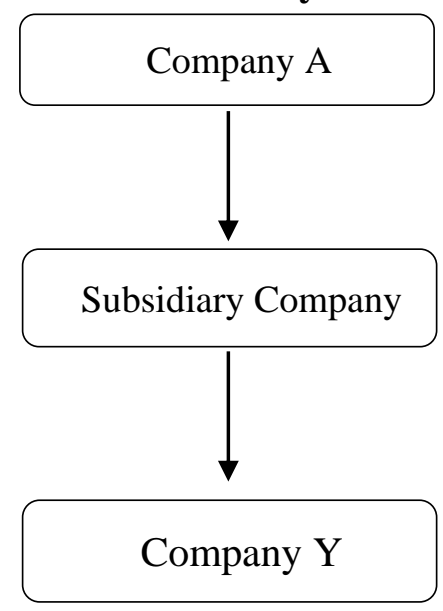

Source: Darussalam, Danny Septriadi, Concept and Application of Cross Border Transfer Pricing for Taxation Purposes, 2008 : 16

2. The same party (can be either a personal or a company) "participates either directly or indirectly in the management, control or share ownership" of company X in country X and company $\mathrm{Y}$ in country $\mathrm{Y}$. 


\section{Special Relationship Scheme}
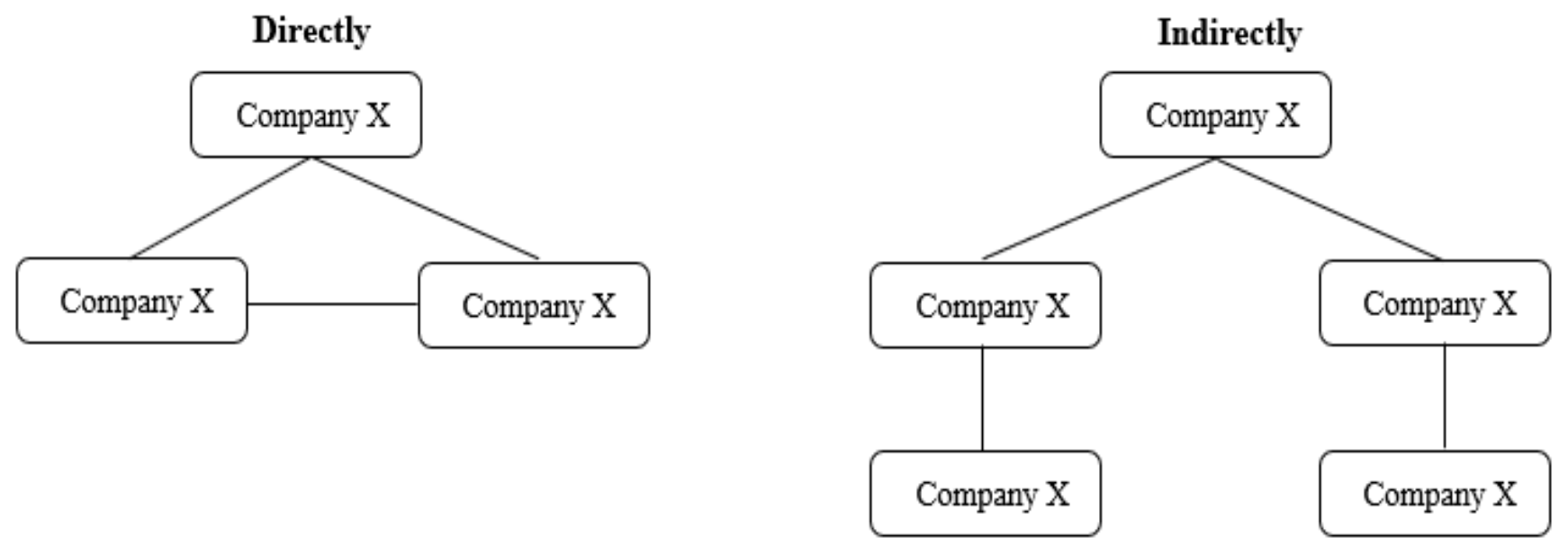

Source: Darussalam, Danny Septriadi, Concept and Application of Cross Border Transfer Pricing for Taxation Purposes, 2008: 16

The OECD model or guidelines do not explain the definition of what is meant by management control, either directly or indirectly. However, according to David Gordon in an International Fiscal Association Congress, as quoted by Darussalam and Septriadi (2008: 16), what is meant by control includes:

1. Has the authority to make decisions related to financial policies in and operation of a company,

2. Has the influence to determine the price set.

Meanwhile, what is meant by participation in management (participation in management) is being involved in making decisions on the operating activities of a company.

\section{Transfer Pricing}

Transfer pricing is a price determinant for management control purposes over the transfer of goods and services, between responsibility centers (Gunadi, Transfer Pricing, 1994: 9). Transfer pricing is carried out to reduce the tax burden, namely by manipulating the prices of goods or services, both tangible and intangible, by companies that have a special relationship with the aim of reducing the global tax burden that must be borne by a company.

Soemitro has its own definition of the meaning of transfer pricing, which is an act of invoicing goods (as well as services) delivered between divisions or branches of a multinational enterprise. Soemitro also emphasized that the invoice price of taxes for goods or services delivered between branches of a multinational company. These transactions usually occur between companies that have a special relationship. (Rochmat Soemitro, 1998).

According to Tsurumi (1984) who was quoted by Gunadi as defining transfer pricing as a price that is calculated for management control over the prices of goods and services between profit and cost responsibility centers (Gunadi, Transfer Pricing, 1994: 9). Tsurumi explained that transfer pricing is used for management purposes for profit and cost responsibility among multinational company branches. Responsibility profit and cost relates to the responsibility of management for company profits and costs.

Transfer pricing transactions are transactions that occur between companies that have a special or affiliated relationship so that the price set rarely follows the market price or fair price, but rather the price that is considered appropriate for the companies conducting the transaction. In the internal economic concept of a company, transfer pricing is one of the tools to reduce the tax burden borne by a company. Transfer pricing manipulation can be done by increasing costs or reducing sales through the transfer price mechanism to reduce tax payments.

\section{Arm's Length Principle}

Based on the literature applicable in Indonesia, the definition of the Arm's Length Principle (ALP) is a principle that regulates that if the conditions in a transaction between parties who have a special relationship are the same or proportional to the conditions in the transaction between parties who do not have a Special Relationship to be compared, then the price or profit in a transaction made between related parties must be the same as or within the price or profit range in a transaction made between parties who are not related to that particular relationship. be a comparison. 
The fair market price in transfer pricing is a price that is set at the time of transactions between companies in a group of companies with a special relationship for tax purposes, but the price that is recognized must always be the same or resemble transactions that occur between companies that are not related to the company. open market. Besides, in a fair market price, there is also a fair market price interval, where there is more than one fair market price in a distance interval.

The principle of arm's length is reflected in the model of the double tax avoidance agreement (tax treaty), both the model from the OECD and the model of the United Nations (United Nation Model). In both models, it is stated that the conditions created or created between two companies in a commercial or financial relationship are different from the conditions that occur between independent companies, then there is an advantage that should be recognized by a company but due to these conditions, the profit becomes not recognized, then the gain must be recognized as the property of the company and be taxed accordingly.

In commercial business, the determination of transfer prices that are not the same as market prices can be driven purely by business policy. Some of these policies, for example, are motivated to gain or maintain market share (market penetration), stimulate the productivity and performance of local managers, raise the rating of companies in certain countries, control the prestige of associated companies, increase the share of joint venture company profits, safeguard subsidiary cash flows. companies and foster good relations with the host government. (Gunadi, Transfer Pricing, 1997: 192).

The difficulty in applying arm's length is that companies that have a special relationship often carry out transactions that are not carried out by independent parties. These transactions are not always motivated to avoid taxes because in the transactions the companies of the or the group face different commercial environments.

\section{RESEARCH METHODS}

The author uses a qualitative explanative method in this research method. The qualitative method is the activity of collecting information or data by means of observation or observation of the running of the agency and obtaining data from the agency's documents or records and finally describing it so that conclusions can be obtained regarding the classification analysis of special relationships based on Indonesian tax law and the Indonesian tax treaty with Japan. The purpose of the explanative method is to provide an explanation or information why something happened. The author obtains information or data through the data collection process with the following techniques:

1. Literature Study

It is a technique of collecting information through written texts such as journals, books, ebooks, articles, government publications, and others.

2. Observation

It is a technique of collecting information by observing directly the object being studied accurately so that it can obtain information about a problem.

3. Documentation

It is a technique of collecting information by understanding in depth company data with the case being studied.

\section{DISCUSSION}

Based on the facts and data that have been collected, in the Corporate Income Tax Return, Audited Financial Statements, and Transfer Pricing Documentation of PT ABC, Japanese companies only have share ownership in PT. ABC of 9.5\%. Whereas the definition related to a special relationship has been regulated based on Article 18 paragraph (4) of the Income Tax Law and based on this provision, Japanese companies are not affiliated parties of PT. ABC based on Article 18 paragraph (4) letters a, b, and c, with the following explanation:

1. A Japanese company that only owns shares of $9.5 \%$ and does not meet the criteria for shared ownership of at least $25 \%$ based on Article 18 paragraph (4) letter an of the Income Tax Law.

2. Japanese companies do not control PT ABC either directly or indirectly, based on:

a. Management mastery, because there is no same name on the position of the Board of Directors (BoD) based on information from the Corporate Income Tax Return of PT ABC and the Japanese Company BoD. Furthermore, in conducting business, PT ABC is independently and not controlled by any party.

b. The use of technology, because there is no use of Japanese company technology used by PT ABC in carrying out its business activities.

3. There is no family relationship either in blood and by marriage between PT ABC and the Japanese company.

Furthermore, related to "control" regulated further in Article 8 paragraph (4) of Government Regulation of the Republic of Indonesia Number 94 of 2010 concerning Calculation of Taxable Income and Payment of Income Tax in the Current Year (PP94/2010):

"The relationship between the parties concerned for ownership or control between the Taxpayer grantor and the recipient Taxpayer 
as referred to in paragraph (1) letter c occurs if there is:

a. $\quad \ldots$

b. the relationship of control directly or indirectly as referred to in Article 18 paragraph (4) letter b of the Income Tax Law."

In more detail, the elucidation of Article 8 paragraph (4) PP-94/2010 provides examples of direct and indirect management control as follows: Direct management control based on the explanation of Article 8 paragraph (4) letter b PP-94/2010 provides the following examples:

Example:

\section{Direct management mastery:}

Mr. A and Mr. B, are the directors of PT X, while Mr. C is the X commissioner. Besides, Mr. C is also a director at PT Y, and $M r . B$ is a commissioner at PT Y. Mr. B Junior is a director at PT AA, while Mr. E a commissioner of PT AA. Mr. B Junior is the son of $M r . B$ who is a director of PT X and a commissioner of PT Y. In the example above, PT X and PT Y have a direct management control relationship because $M r . B$ in addition to working as a director at PT X also works as a commissioner PT Y. Also, Mr. C in addition to working as a commissioner at PT X works as a director at PT Y. If PT X receives assistance or donations from PT Y (or vice versa) then the assistance or contribution is a tax object for the party receiving. Likewise, PT Y and PT AA have a direct management control relationship, because there is a family relationship between $M r$. B (father) who works as a commissioner at PT $Y$, and Mr. B Junior (son) who works as a director at PT AA. If PT AA receives assistance or donations from PT Y (or vice versa) then the assistance or contribution is a tax object for the recipient. If Mr. B.Jr (child) receives assistance or donations or gifted assets from $M r . B$ (father) then the assistance or donations or gifted assets are exempted from the Income Tax object as referred to in Article 4 paragraph (3) letter an of the Income Tax Law. , because those who have a management control relationship are between PT Y and PT AA, not between Mr. B (father) and Mr. B Junior (son). Thus, management tenure relationships only occur between entities that have the same management or have family relationships. Meanwhile, the management in the entity does not have a control relationship."

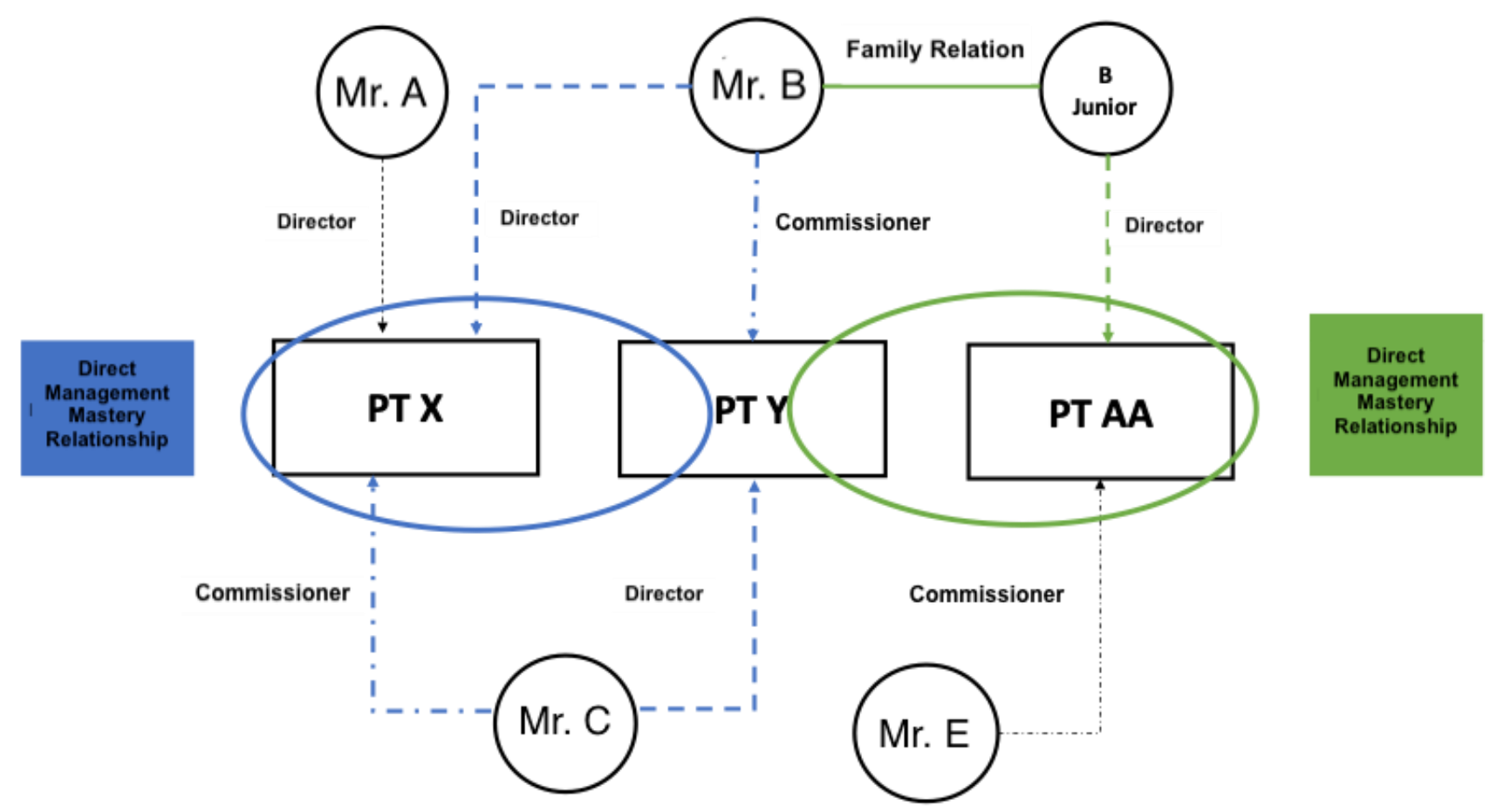

Based on the example, the scheme, as well as the evidence of the Board of Directors / BoD list above, it is clear that between PT ABC and the Japanese company no manager who is the same or has a family relationship so it is clearly proven that there is no direct management control over PT ABC. by a Japanese company.

\section{Indirect management mastery:}


Whereas further the Elucidation of Article 8 paragraph (4) PP-94/2010 provides the following examples: Mr. O is a director of PT AB, and Mr. P is a commissioner of PT AB. Mr. O and Mr. P clearly have the authority to determine policies and/or make decisions in the context of carrying out PT X's activities, for example having the authority to sign contracts with third parties, sign checks, and so on even though Mr. O and/or Mr. the management stated in the deed of establishment and deed of change of PT X. In the example above, PT AB and PT X have an indirect management control relationship. " To make it easier to analyze the example above, the author describes it in the following scheme:

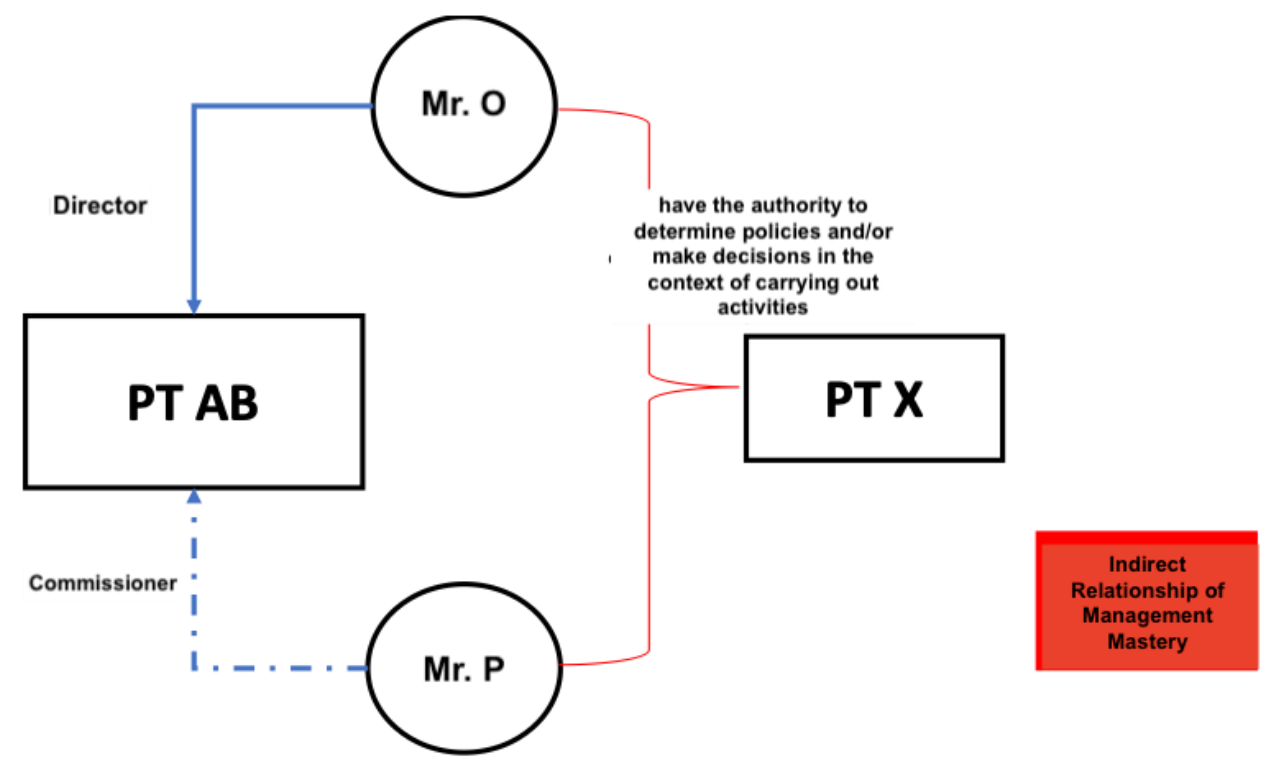

Based on the example, the scheme, as well as existing evidence, it is clearly proven that Japanese companies do not have the authority to determine policies and/or make decisions in the context of carrying out PT ABC activities, for example, the authority to sign contracts with third parties, sign checks, etc. there is no indirect management control over PT ABC by a Japanese company.

That the authority to conduct a fairness analysis of affiliated transactions must be based on domestic regulations/provisions including Article 18 paragraph (3) and paragraph (4) of the Income Tax Law and Article 8 paragraph (4) PP-94/2010 because Tax Treaty cannot create and expand rights taxation regulated in said domestic taxation provisions. Article 9 Tax Treaty Indonesia and Japan regulate the determination of the special relationship between a Taxpayer and other Taxpayers as follows:

"Where:

a. an enterprise of a Contracting State participates directly or indirectly in the management, control or capital of an enterprise of the other Contracting State, or

$b$. the same persons participate directly or indirectly in the management, control or capital of an enterprise of a Contracting State and an enterprise of the other Contracting State,

and in either case, conditions are made or imposed between the two enterprises in their commercial or financial relations which differ from those which would be made between independent enterprises, then any profits which would, but for those conditions, have accrued to one of the enterprises, but, because of those conditions, have not so accrued, may be included in the profits of that enterprise and taxed accordingly."

Based on the explanation above, a special relationship is because there is a company that is directly or indirectly in the management, control, or capital of another company. Furthermore, a special relationship occurs because there are the same people who participate directly or indirectly between the company and other companies.

Furthermore, the OECD Model Convention regulates as follows:

"Commentary on Article 9 concerning the Taxation of Associated Enterprises Paragraph 2 [Adjustments of profits] ...No rewriting of the accounts of associated enterprises is authorized if the transactions between such enterprises have taken place on normal open market commercial terms (on an arm's length basis)..."

In Indonesian, this means:

"Komentar tentang Pasal 9 tentang Perpajakan dari Perusahaan yang memiliki Hubungan Istimewa Ayat 2 [Penyesuaian laba] .. Tidak ada penulisan ulang akun perusahaan terkait yang diotorisasi jika transaksi antara perusahaan tersebut telah terjadi dengan persyaratan komersial pasar terbuka yang normal (atas dasar yang wajar) ... "

Furthermore, based on the above explanation, the classification of special relations based on Tax Treaty Indonesia and Japan is quite broad compared to the Domestic Law, which can be illustrated as follows. 


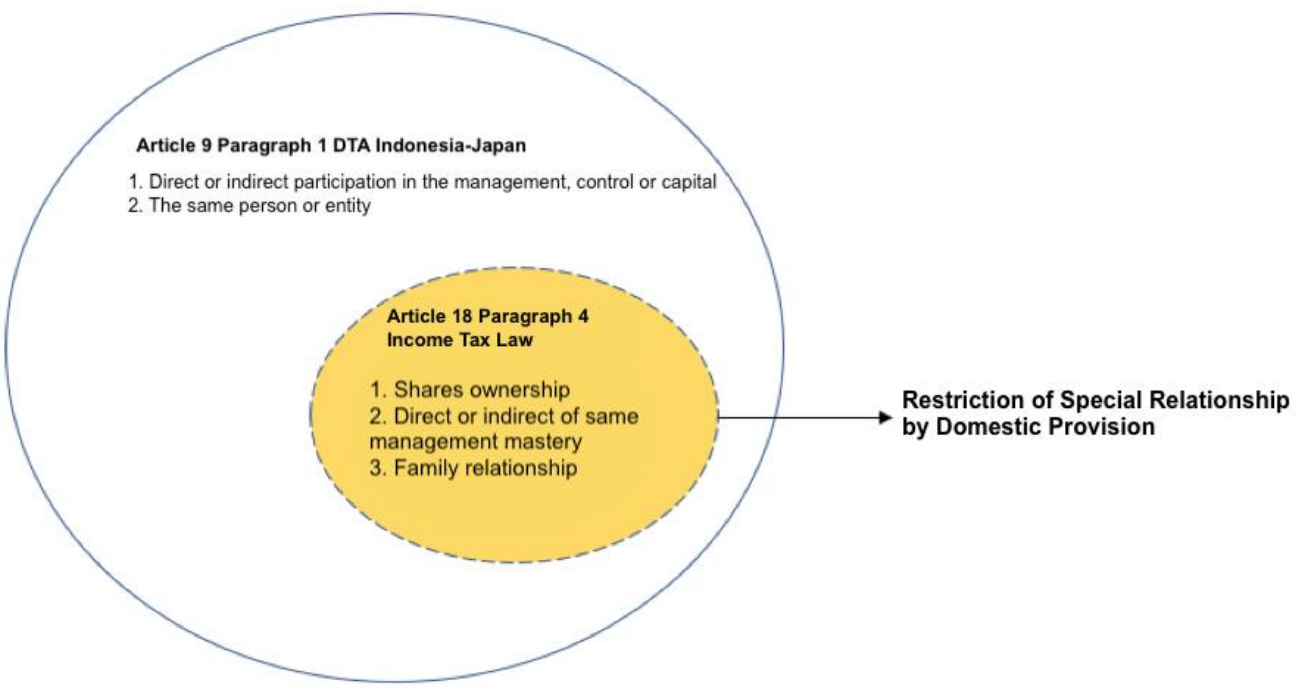

Furthermore, even though the provisions of Tax Treaty are special (lex specialist), the provisions of Tax Treaty, especially Article 9 of Tax Treaty Indonesia and Japan should be interpreted as provisions that cannot be directly implemented/No SelfExecuting Character. Based on Main features of Article 9 OECD and UN MC:

"Whether or not a Contracting State may avail itself of the treaty authorization under Article 9(1) OECD and UN MC depend on its own domestic law; Article 9(1) OECD and UN MC do not create any legal basis for rewriting taxpayers' accounts (infra m.no.10 et seq.). All Article 9 (1) OECD and UN MC do are to restrict domestic law to the extent that the latter provides forprofit adjustments between associated enterprises beyond those permissible under the arm's length principle (infra m.no.12 et seq.)."

In Indonesian: Main features of Article 9 of the OECD and UN MC

Dapat atau tidaknya suatu Negara pihak untuk dapat memanfaatkan sendiri kewenangan perjanjian (P3B) berdasarkan Pasal 9 (1) OECD dan UN MC tergantung pada hukum domestiknya sendiri; Pasal 9 (1) OECD dan UN MC tidak membuat dasar hukum untuk menghitung ulang akun wajib pajak (infra m.no.10 et seq.). Pasal 9 (1) OECD dan UN MC adalah untuk membatasi hukum domestik sejauh yang disebutkan terakhir memberikan kewenangan dalam penyesuaian laba antara perusahaan berafiliasi di luar yang diizinkan berdasarkan prinsip kewajaran dan kelaziman usaha (infra m.no.12 et seq).

Thus, it can be concluded that:

a. The authority of Article 9 paragraph (1) of the Tax Treaty depends on domestic (Indonesian) law and does not provide new taxation rights.

b. Article 9 paragraph (1) in nature will limit domestic provisions in the case of adjustment in transfer pricing that is carried out over of Arm's Length Principle.

The provisions of Article 9 of the Tax Treaty cannot be directly implemented/No Self-Executing Character. Whereas Goerg Kofler, in the book Klaus Vogel on Double Taxation Conventions 4th Ed., 2015 states that Article 9 Tax Treaty in principle follows:

\section{a. $\quad$ No Self-executing Character}

"When considering the treaty rules corresponding to Article 9 OECD and UN MC, it should again be noted that DTCs merely restricts, rather than generate, domestic taxing rights. Although a higher tax burden may - in theory-result from the application of a tax treaty (see no. 9.2 OECD MC Comm. On Article 1), there is a broad consensus in case law, among tax authorities, and in legal scholarship that Article 9(1) OECD and UN MC cannot, by itself, be an independent legal basis for upward income adjustments. Conversely, there is no treaty obligation for a Contracting State to make a primary adjustment, even if the conditions of Article 9 OECD and UN MC are fulfilled; the wording of Article 9(1) OECD and UN MC (i.e., the use of 'may' rather than 'shall') makes clear that the Contracting States are not obliged to exercise the authority granted by the provision. The prevailing view is therefore that the only legal basis for profit adjustments between associated enterprises is applicable domestic laws; Article 9 (1) OECD and UN MC does not have 'self-executing character'..."

\section{b. $\quad$ Restriction of Domestic Taxing Rights}

As noted before, the only legal basis for profit adjustment between associated enterprises is the applicable domestic law. ..."

In Indonesian, this means: 


\section{a. Tidak dapat secara langsung dilaksanakan /No Self-Executing Character}

Ketika mempertimbangkan aturan perjanjian yang sesuai dengan Pasal 9 OECD and UN MC, perlu diperhatikan bahwa DTC hanya membatasi, bukannya menghasilkan, hak perpajakan domestik. Meskipun beban pajak yang lebih tinggi dapat - dalam teori dapat terjadi dari penerapan perjanjian pajak (lihat paragraf 9.2 OECD Komentar dalam Model Konvensi untuk Pasal 1), adanya konsensus yang lebih luas dalam kasus hukum, antara otoritas pajak dan para ahli hukum berpendapat bahwa Pasal 9 (1) OECD dan UN MC tidak dapat, dengan sendirinya, menjadi dasar hukum yang independen untuk melakukan koreksi lebih tinggi atas pendapatan. Sebaliknya, tidak ada kewajiban dalam perjanjian (P3B) bagi salah satu Negara Pihak pada perjanjian untuk melakukan koreksi primer harga transfer, bahkan jika persyaratan Pasal 9 OECD dan UN MC dipenuhi; kalimat dalam Pasal 9 (1) OECD dan UN MC (yaitu penggunaan kata 'dapat' daripada 'wajib') memperjelas bahwa kedua Negara Pihak dalam perjanjian tidak berkewajiban untuk melaksanakan wewenang yang diberikan oleh pasal tersebut. Oleh karena itu, pandangan yang sekarang berlaku adalah bahwa dasar aturan satu-satunya untuk melakukan koreksi laba antara pihak-pihak yang berafiliasi adalah hukum domestik yang berlaku; Pasal 9 (1) OECD dan UN MC tidak memiliki "Tidak dapat secara langsung dilaksanakan/No Self-Executing Character". Dengan demikian satu-satunya dasar hukum untuk koreksi pendapatan antara perusahaan yang berafiliasi adalah hukum domestik yang berlaku.

\section{CONCLUSION}

Based on the explanation above, it can be concluded that determining whether PT ABC has an affiliated relationship or not with a Japanese company and whether Fiskus has the authority to make corrections to affiliated transactions or not, should be based on domestic regulations/provisions including Article 18 paragraph (3) and paragraph (4) The Income Tax Law and Article 8 paragraph (4) PP-94/2010 in other words Tax Treaty does not create tax objects/taxation rights. Therefore, in interpreting Article 9 of the Tax Treaty Indonesia and Japan, it is necessary to consider the following:

a) The articles stipulated in the Tax Treaty are in principle only limited and do not result in new domestic taxation rights.

b) The classification of special relations in Article 9 of the Tax Treaty Indonesia and Japan cannot automatically be an independent legal basis for making a higher adjustment to income. The main legal basis for determining criteria for affiliation should be based on domestic conditions.

c) The use of the word 'can' in Article 9 of Tax Treaty Indonesia and Japan where "... any profits that should fall on one of the companies, but which are not obtained because of these conditions, can be added to the profits of the company and subject to tax ..." makes it clear that both The Contracting State party is not obliged to exercise the authority given by that article so that the sole rule for conducting profit adjustments between affiliated parties is applicable domestic law. 


\section{REFERENCES}

Darussalam, Septriadi. 2008, Cross Border Transfer Pricing untuk Tujuan Perpajakan, Jakarta: Danny Darussalam Tax Center.

Internasional Tax.

John. Hutagaol, dany Danny Septriadi. 2010, Konsep dan Aplikasi Perpajakan Internasional, Jakarta: PT Dimensi

Gunadi. 1999, Pajak Internasional, edisi Revisi, Jakarta : Lembaga Penerbit Fakultas Ekonomi Universitas Indonesia.

. 2002, Ketentuan Dasar Pajak Penghasilan,Jakarta: Salemba Empat.

Transfer Pricing Tinjauan Akuntansi, Manajemen, dan Pajak, Jakarta: PT. Bina Rena Pariwara, 1994

Rosdiana, Haula dan Edi Slamet Irianto. 2012, Pengantar Ilmu Pajak: Kebijakan dan Implementasi di Indonesia, Jakarta : Rajawali Pers.

Rust, Alexander. 2015, Klaus Vogel on Double Taxation Conventions 4th Ed., Kluwer Law International

Soemitro, Rochmat. 1991, Asas - asas hukum perpajakan.Bandung: Binacipta.

Wisanggeni, I. (2019). PAJAK INTERNASIONAL - Tinjauan Praktis. Jakarta: Mitra Wacana Media. 